\title{
The Impact of Climate Change on Hydrology with Geomorphology in Northeast Texas
}

\author{
Joonghyeok Heo \\ Physical Sciences Department, University of Texas Permian Basin, Odessa, Texas 79762, USA
}

\begin{abstract}
This research evaluates the responses of hydrology and geomorphology regarding climate change and illustrates the change in regional streamflow during the period 1955-2001. The Neches River Basin, Texas, is an important source of water for farming, cities, and electrical power production. A $15.9 \%$ increase in precipitation and a $20.4 \%$ increase in streamflow discharge were observed. The areas of river-flow boundaries also increased. The hydrologic changes appear to be associated with the geomorphic adjustments. To accomplish this research, the Neches River Basin is evaluated using hydro-climate data, historical aerial photography, and GIS in a multiscale approach by using linked geomorphic systems. Changes in the streamflow discharge are main factors that must be considered in undertaking a hydrological impact assessment of climate change.
\end{abstract}

Key words: Hydrology, Texas, water resources, Neches River Basin, climate change.

\section{Introduction}

Neches River Basin is one of the largest river systems in Texas. The basin plays a fundamental role in the interaction between ecological and economical processes. It also provides an important resource of water for agriculture, urban centers, and hydropower production. Several cities are located along the Neches River Basin, including Tyler, Evadale, and Beaumont. However, water resources are becoming increasingly important because of current and potential future impacts of climate change, constantly increasing population growth and economic development [1]. Thus, understanding and evaluating the impact of climate change on Neches River Basin is critical for the water resource management.

Texas has experienced distinct climate changes during the last century [2]. Temperature has increased in past few decades, and the increasing rate in Texas has been more rapid than elsewhere [3]. Precipitation has increased in Texas and the change of precipitation is more dramatic than that of temperature [4]. The

Corresponding author: Joonghyeok Heo, assistant professor of geology, research fields: hydrology, water resources management, geologic applications to energy production, modeling investigation. analysis of precipitation and temperature records indicates the trends and periodicity in climate change [5]. The analysis of the historical climate records can provide a reference dataset for the potential effects of climate change on water resource.

Previous studies have been undertaken to evaluate the response of water resources to climate change [6-9]. The incidence of severe precipitation promotes increased amounts of surface runoff causing a higher flood frequency [10]. Heo et al. [11] showed that East Texas had a $16.3 \%$ increase in precipitation during the period 1970-2009, which eventually led to increases of surface runoff $(15.0 \%)$ and soil water content (2.7\%). In general, climate change develops the variation of precipitation, which directly influences streamflow and water resources issues [12].

Some studies represented strong positive correlation between climate and geomorphology [13, 14]. Streams respond to a hydrologic disturbance by altering their channel dimensions, meander wavelength, and sinuosity [15]. The response of river systems to climate change can be aggradation, degradation, lateral migration, or changes in the channel geometry and sediment load [16]. Severe precipitation events can also trigger substantial 
geomorphic change such as erosion or sediment yield [17]. Climate change influences the geomorphic characteristics of streams by affecting the frequency and magnitude of stream discharge [18, 19].

Climate change has been recognized as one of the greatest influences stressing water resources, but the quantitative estimate of geomorphic change is also essential for understanding the potential water resource management. Furthermore, relatively little research has been undertaken regarding the potential impact of climate change on water resources with geomorphology in Texas. This research focuses on the interaction of climate change and water resources with geomorphic changes in the Neches River Basin, Texas, from 1955 to 2005 . To fulfill the goal of this research, the following objectives have been evaluated; (1) the historical change of precipitation during 1955-2005 and (2) the streamflow discharge in relation to river channel changes in Neches River Basin, Texas. Understanding the interactions can offer opportunities not only to understand hydrologic systems, but also to suggest directions for future environmental management.

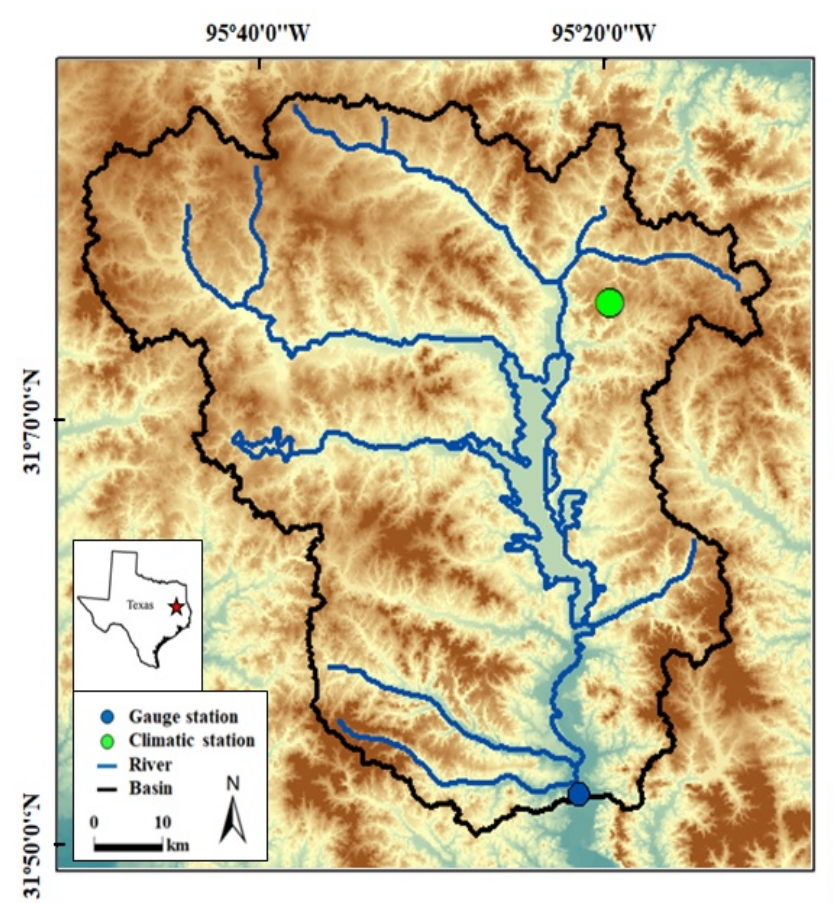

\section{Study Area and Data Set}

The study area is located in northeast Texas, USA, which is a part of Neches River Basin (Fig. 1). It has a total area of $25,921 \mathrm{~km}^{2}$ and a gradient drop of $161 \mathrm{~m}$. The river flows into the Sabine Lake near Beaumont, Texas, and ultimately into the Gulf of Mexico. The major towns along the river are Tyler, Lufkin, Beaumont, Jasper, and Nacogdoches. Thus, it is an important source of water for agriculture, urbanization, and hydropower production. The climate of the study area is predominantly humid subtropical climate with an annual average temperature ranging of $19.1^{\circ} \mathrm{C}$ and an annual total precipitation of $1,425.4 \mathrm{~mm}$ based on the 1955-2001 data of Jacksonville, TX weather station. Vegetation of the area consists mainly of grasses, aspen groves (Populus tremuloides), and pines (Pinus edulis). The study area consists mainly of sandstone, mudstone and shale.

The study area was chosen for the following reasons: (1) it has a relatively long-running climatic and hydrological observation network, and (2) it has several towns and industrial enterprise lying within

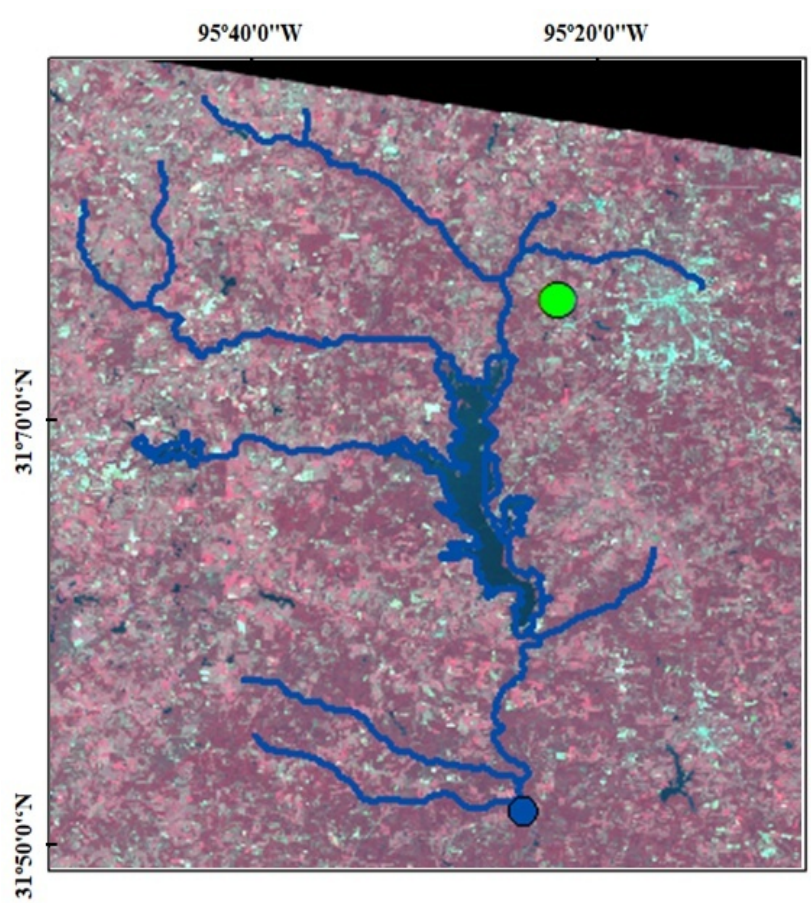

Fig. 1 The location map of the study area: (a) DEM (Digital elevation model) and watershed boundary, and (b) Landsat ETM and Naches River. 
the river basin. Hydrology, climate, and geomorphology data have been obtained for the period 1955-2001. Streamflow discharge data for the gauge station (08032000, Neches Rv nr Neches, TX) were collected from the NWIS (National Water Information System) of the USGS (U.S. Geological Survey). Precipitation and temperature data were obtained from the NOAA (National Oceanic and Atmospheric Administration) and USDA (U.S. Department of Agriculture). Historic aerial photographs and DEM (digital elevation model) were collected from TNRIS (Texas Natural Resource Information System) and USGS, which were used for the analysis of geomorphic change.

\section{Methodology and Results}

\subsection{Methodology}

The annual data were calculated from the daily data, which applied for trend analysis of hydrology and climate change. There were some missing hydro-climate data because of illegible or irregular measurement in the NCDC (National Climate Data Center) of NOAA. For stations with missing data, monthly mean values were used for trend analysis in the study area [20]. To evaluate the effect of spatial precipitation variation, we applied IDW (Inverse Distance Weighted), which is the most powerful techniques for interpolation of scatter points. IDW

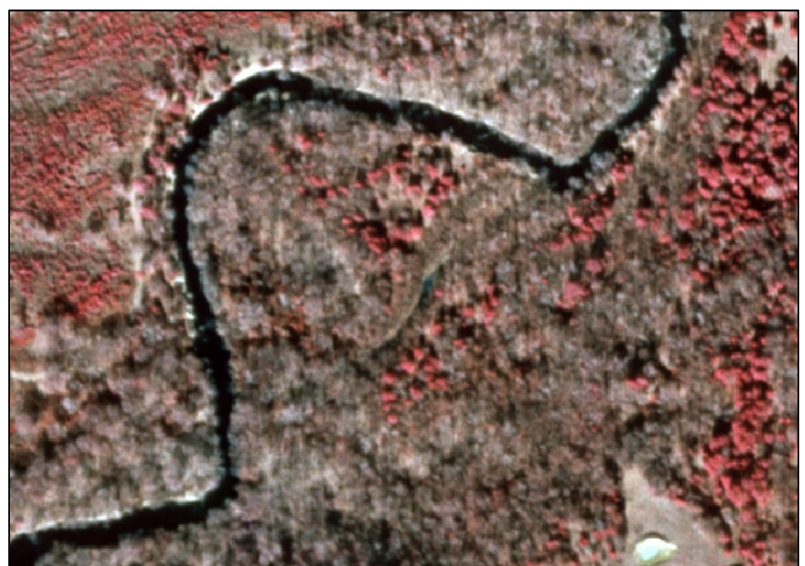

Fig. 2 Example for SVM classification in the study area: (a) river channel in aerial photograph image and (b) SVM classification in aerial photograph image. method is used for the estimation of spatial information in hydrology and climatic sciences. It is based on the assumption that the influence of a measured point is weighted according to the distance from the sampled point to the estimated point.

We applied SVM (Support Vector Machine) classification for river water-flow boundary delineation (Fig. 2). SVM classification is a very effective method for solving supervised classification and regression problems from complex, noisy data (Yu et al., 2010). Based on the statistical learning theory, it provides good classification results from complex and noisy data. SVM classification was completed via manual interpretation of historical aerial photography in the study area. It aims to attain the best generalization by balancing the relationship between the accuracy achieved on a given finite quantity of training data and the machine capacity. Based on SVM classification, we calculated for the total area of river channel using ArcGIS.

\subsection{Results and Discussion}

Streamflow is an important pathway of water resources and represents the amount of water in a river channel. It indicates the number of volume of flow passing a defined point over a specific time period [21]. Fig. 3 shows the volume of streamflow and annual total precipitation in the study area.

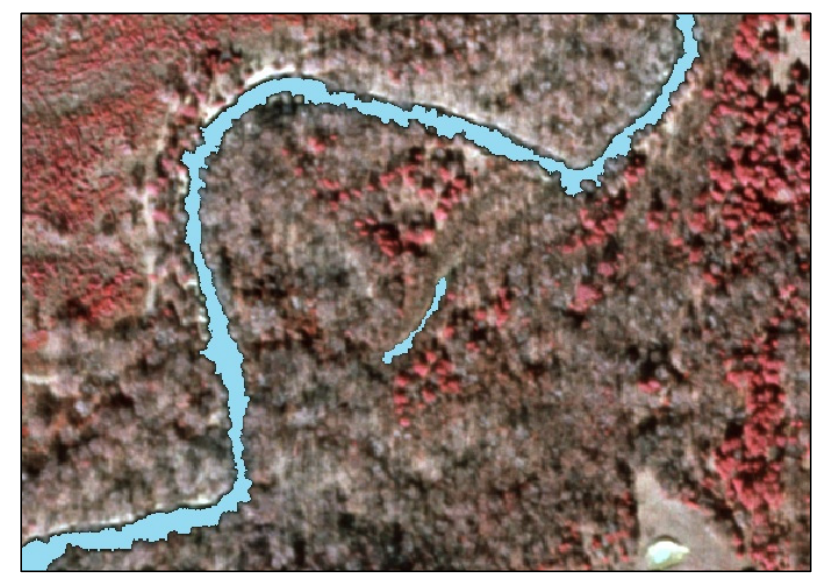




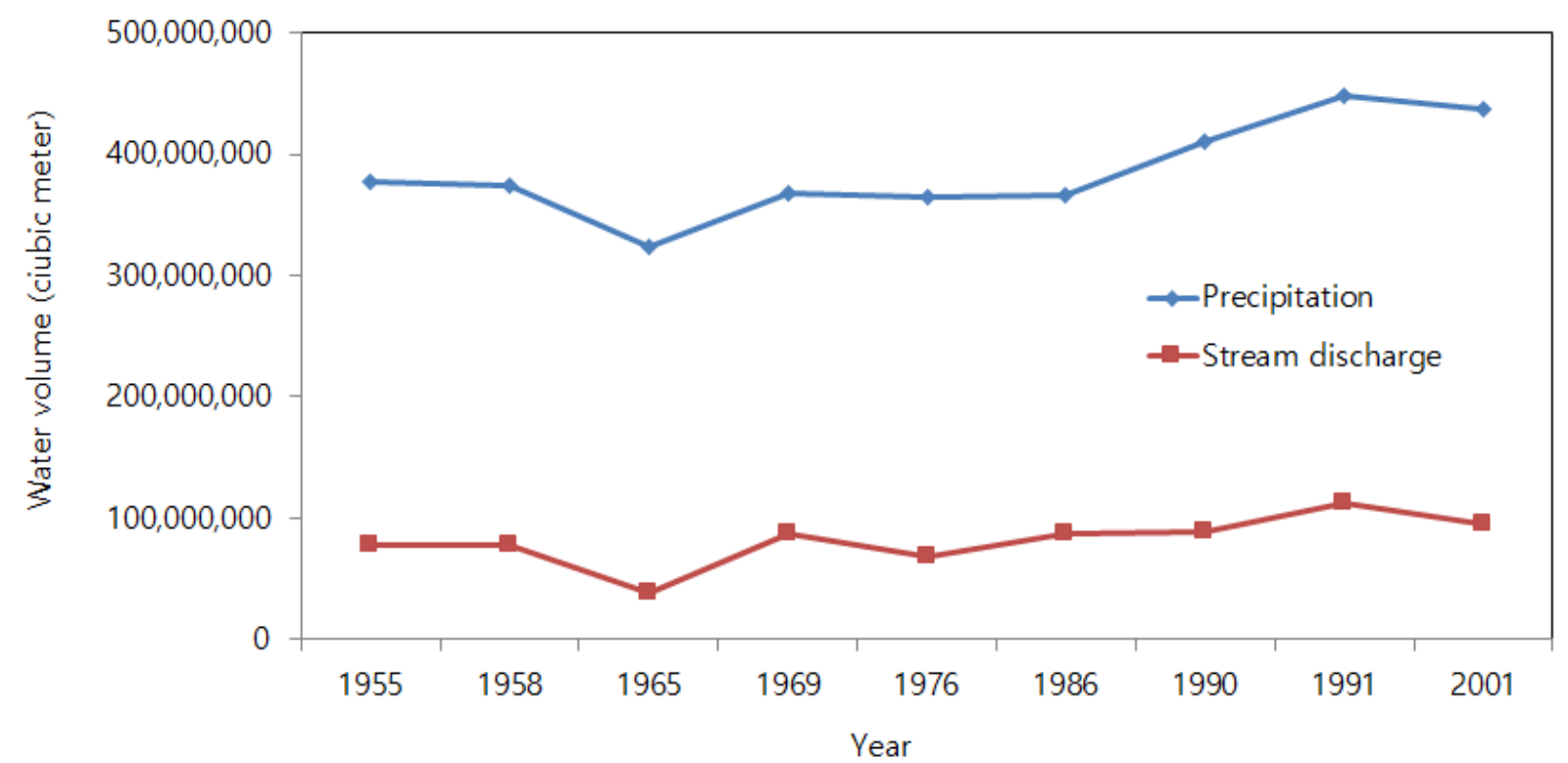

Fig. 3 Annual total precipitation and streamflow discharge for the observed periods (unit: cubic meter year).

Table 1 Proportion of streamflow discharge to total precipitation (unit: \%).

\begin{tabular}{ll}
\hline Year & Proportion (stream discharge/precipitation, \%) \\
\hline 1955 & 20.9 \\
1958 & 20.6 \\
1965 & 11.7 \\
1969 & 23.5 \\
1976 & 18.9 \\
1986 & 23.6 \\
1990 & 21.5 \\
1991 & 25.0 \\
2001 & 21.7 \\
\hline
\end{tabular}

Streamflow discharge for 1955 and 2001 was $\sim 79,000,000$ and $\sim 95,000,000 \mathrm{~m}^{3} /$ year, respectively, which accounts for $20.9 \%$ and $21.7 \%$ of the total precipitation (Table 1 ). Overall, about $\sim 80 \%$ of the precipitation was lost as evapotranspiration, soil water, or groundwater. The percentage of contribution to the annual total precipitation was relatively stable as the values showed. Annual total precipitation increased $15.9 \%$ from $\sim 376,000,000$ to $\sim 436,000,000 \mathrm{~m}^{3} /$ year, for the period 1955-2001. We also estimated the spatial distribution of precipitation using IDW interpolation (Fig. 4). The study area followed a general increasing pattern in precipitation and we think this suggests that the general increase in precipitation in this study is a global phenomenon.

The changes in hydro-climate data in the study area can be summarized as a $15.9 \%$ in precipitation and a $20.4 \%$ in streamflow discharge. Areas with high precipitation experience increase in streamflow discharge, whereas areas with low precipitation experience decrease in streamflow discharge [22]. Collins and Knox [23] explained that variation in streamflow reflects the inter-annual change in the amount of surface runoff as influenced by climate factors such as precipitation. Streamflow discharge in the study area has a similar pattern to that of precipitation (Fig. 3). This change suggests that streamflow discharge in the study area is directly influenced by precipitation.

We investigated the delineation of river-flow boundaries from historical aerial photography and quantitatively measured the areas of river-flow boundaries in the study area using SVM classification. As shown in Table 2, the area of river-flow boundaries was $10.1 \mathrm{~km}^{2}$ in early $1970 \mathrm{~s}$ (Landsat MSS) and 11.4 $\mathrm{km}^{2}$ in late 1990s (Landsat ETM+). In fact, the area showed a generally increasing pattern from 1970s to 1990s. Geomorphic change can be affected by climate variations [24, 25]. High amounts of precipitation and 

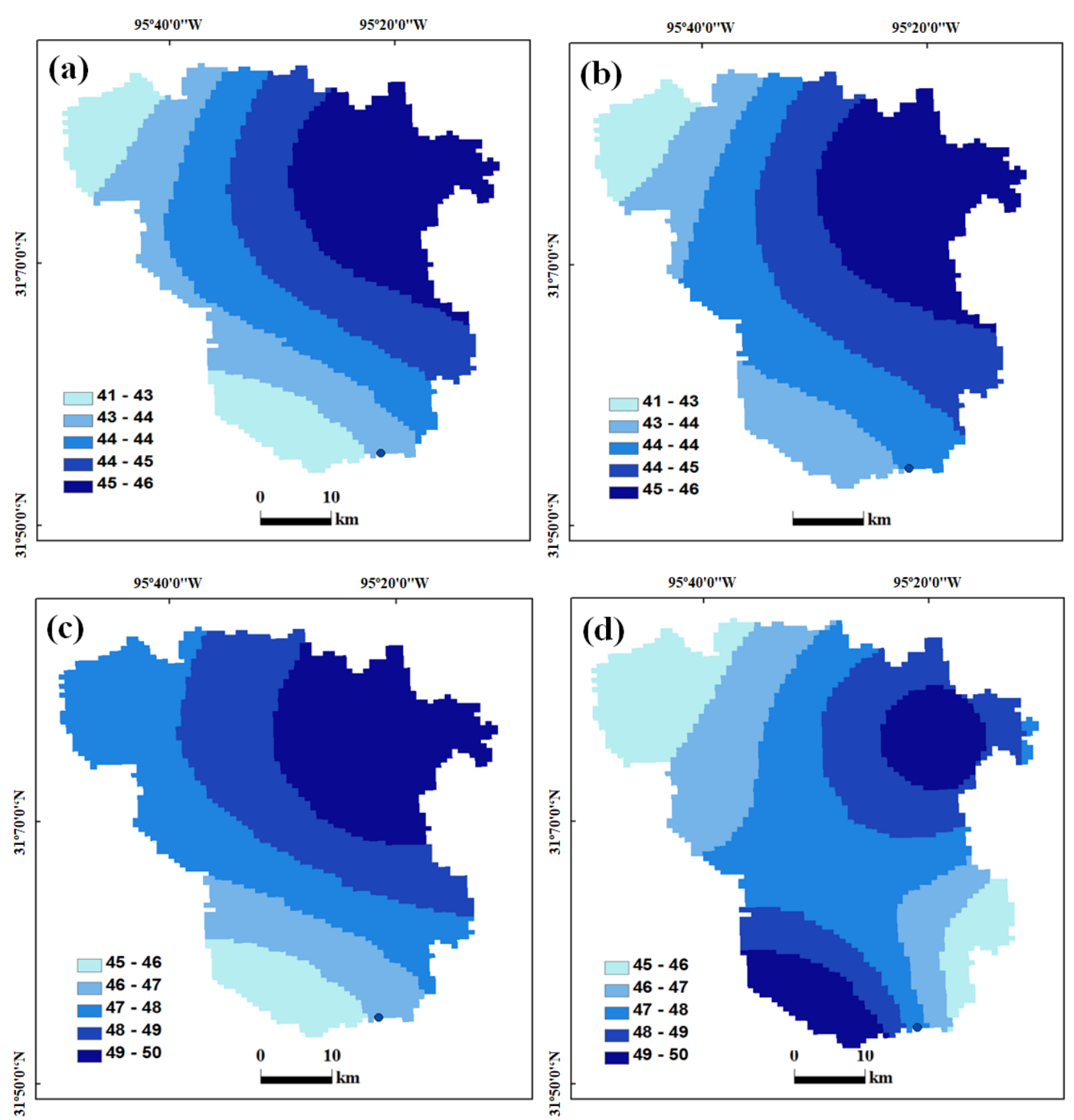

Fig. 4 Spatial distribution of total precipitation in the study area; (a) 1955, (b) 1972, (c) 1986, and (d) 2001.

Table 2 Changes of river-flow boundaries in the study area.

\begin{tabular}{ll}
\hline Year (aerial photography) & $\begin{array}{l}\text { Area of river-flow } \\
\text { boundaries }\left(\mathrm{km}^{2}\right)\end{array}$ \\
\hline 1972 (Landsat MSS) & 10.1 \\
1984 (Landsat TM) & 10.6 \\
1999 (Landsat ETM+) & 11.3 \\
\hline
\end{tabular}

surface water discharges are important in building channel morphology [26]. Frequent weather extremes (i.e. heavy precipitation and flood) result in an increase in the width of river channel [27]. We think that the general increase in streamflow discharge in this study area was affected by increasing precipitation. Environmental conditions, such as overhanging trees and Sun angle, reduce the accuracy by impeding the SVM classification because the land-water interface can be obscured [28]. More research is needed to further evaluate the change in river-flow boundaries and improve the accuracy of delineated boundaries.

\section{Conclusions}

This study investigated the impact of climate changes on hydrology and geomorphology in Northeast Texas during 1955-2001. We found 15.9\% increase in precipitation and $20.4 \%$ increase in streamflow discharge. Streamflow discharge follows a 
general increasing pattern for that of precipitation. This study identified that $\sim 80 \%$ of the total precipitation was lost as evapotranspiration, soil water content, groundwater discharge or storage. Variations in the amount of streamflow discharge exist in the Neches River Basin and these variations reflect difference in the hydrology and topography of the study area. This research provides a better understanding of the complex interplay of climate change and its effects on the hydrology and geomorphology in Northeast Texas. This research can also contribute to current knowledge of the effects of climate change on water resources and demonstrate the effectiveness of the integrated approach in predicting the impact of future geomorphic changes in context of future climate change.

\section{Acknowledgments}

This work was supported by the University of Texas System Rising STARs Program Funding.

\section{References}

[1] IPCC (Intergovernmental Panel on Climate Change). 2014. "Climate Change 2014: Synthesis Report." IPCC. Geneva, Switzerland. Available at https://www.ipcc.ch/report/ar5/syr/.

[2] USGCRP (U.S. Global Change Research Program). 2014. "Climate Change Impacts in the United States." Available at http://www.globalchange.gov.

[3] Arnold, J. G., Srinivasan, R., Ramanarayanan, T. S., and DiLuzio, M. 1999. "Water Resources of the Texas Gulf Basin.” Water Science and Technology 39: 121-33.

[4] Loaiciga, H. A., Maidment, D. R., and Valdes, J. B. 2000. "Climate-Change Impacts in a Regional Karst Aquifer, Texas, USA.” Journal of Hydrology 227: 173-94.

[5] O'Connell, S. M., and Watkins, D. W. 2003. "Probabilistic Forecasts Using Climate Information for Water Management in Central Texas." World Water and Environmental Resources Congress. Philadelphia, Pennsylvania.

[6] Limaye, A. S., Boyington, T. M., Cruise, J. F., Uulus, A., and Brown, E. 2001. "Macroscale Hydrologic Modeling for Regional Climate Assessment Studies in the Southeastern United States." Journal of the American Water Resources Association 37: 709-22.

[7] Giambelluca, T. W. 2005. "Land Use and Water
Resources under a Changing Climate." Encyclopedia of Hydrological Sciences 189: 1-7.

[8] Christensen, N. S., Wood, A. W., Voisin, N., and Lettenmaier, D. P. 2004. "The Effect of Climate Change on the Hydrology and Water Resource of the Colorado River Basin." Climatic Change 62 (3): 337-62.

[9] Heo, J., Yu, J., Giardino, R., and Cho, H. 2015. "Water Resources Response to Climate and Land-Cover Changes in a Semi-arid Watershed, New Mexico, USA." Terrestrial, Atmospheric and Oceanic Sciences 26 (4): 463-74.

[10] Ma, X., Xu, J., Luo, Y., Aggarwal, S. P., and Li, J. 2009. "Response of Hydrological Processes to Land-Cover and Climate Changes in Kejie Watershed, South-West China.” Hydrological Processes 23: 1179-91.

[11] Heo, J., Yu, J., Giardino, R., and Cho, H. 2015. "Impacts of Climate and Land-Cover Changes on Water Resources in a Humid Subtropical Watershed: A Case Study from East Texas, USA.” Water Environmental Journal 29 (1): 51-60.

[12] Li, Z., Liu, W., Zhang, X., and Zheng, F. 2009. "Impacts of Land Use Change and Climate Variability on Hydrology in an Agricultural Catchment on the Loess Plateau of China." Journal of Hydrology 377: 35-42.

[13] Huisink, M. 2000. "Changing River Styles in Response to Weichselian Climate Changes in the Vecht Valley, Eastern Netherlands." Sedimentary Geology 133: 115-34.

[14] Blum, M. D., and Tornqvist, T. E. 2000. "Fluvial Responses to Climate and Sea-Level Change: A Review and Look Forward." Sedimentology 47: 2-48.

[15] Hughes, M. L., McDowell, P. F., and Marcus, W. A. 2006. "Accuracy Assessment of Georectified Aerial Photographs: Implications for Measuring Lateral Channel Movement in a GIS." Geomorphology 74: 1-16.

[16] Latrubesse, E. M. 2008. "Patterns of Anabranching Channel: The Ultimate End-Member Adjustment of Mega Rivers." Geomorphology 101: 130-45.

[17] Chang, H., Evans, B. M., and Easterling, D. R. 2001. "The Effects of Climate Change on Stream Flow and Nutrient Loading." Journal of the American Water Resources Association 37 (4): 973-86.

[18] Knight, C. G., Chang, H., Staneva, M. P., and Kostov, D. 2001. "A Simplified Basin Model for Simulating Runoff: The Struma River GIS.” Professional Geographer 53 (4): 533-45.

[19] Vandenberghe, J. 2003. "Climate Forcing of Fluvial System Development: An Evolution of Ideas." Quaternary Science Reviews 22 (20): 2053-60.

[20] Qian, T., Dai, A., and Trenberth, K. E. 2007. "Hydroclimatic Trends in the Mississippi River Basin from 1948 to 2004." Journal of Climate 20 (18): 4599-614. 
[21] Ziegler, A. D., Maurer, E. P., Sheffield, J., Nijssen, B., Wood, E. F., and Lettenmaier, D. P. 2005. "Detection Time for Plausible Changes in Annual Precipitation, Evapotranspiration, and Streamflow in Three Mississippi River Sub-basins." Climatic Change 72: 17-36.

[22] Sun, H. 2004. "Estimating the Fate of Precipitation from Stream Discharge: A Case Study in New Jersey." New Jersey Academy of Science 49: 9-15.

[23] Collins, M. J., and Knox, J. C. 2003. "Historical Changes in Upper Mississippi River Water Areas and Islands." Journal of the American Water Resources Association 39 (2): 487-500.

[24] Gurnell, A. M., Peiry, J. L., and Petts, G. E. 2005. "Using Historical Data in Fluvial Geomorphology." In Tools in
Fluvial Geomorphology, UK: John Wiley \& Sons, Chapter 4.

[25] Goudie, A. S. 2006. "Global Warming and Fluvial Geomorphology.” Geomorphology 79: 384-94.

[26] Kelin, X. W., Eric, K., and Brocklehurst S. H. 1999. "Geomorphic Limits to Climate-Induced Increases in Topographic Relief." Nature 401: 39-43.

[27] Knox, J. C. 1993, "Large Increase in Flood Magnitude in Response to Modest Change in Climate." Nature 361: 430-2.

[28] Guneralp, I., Filippi, A. M., and Hales, B. U. 2013. "River-Flow Boundary Delineation from Digital Aerial Photography and Ancillary Images Using Support Vector Machines." GIScience and Remote Sensing 50: 1-25. 